\title{
Cytokinin cross-talking during biotic and abiotic stress responses
}

\author{
José A. O'Brien ${ }^{1,2}$ and Eva Benková ${ }^{1,2,3}$ * \\ 1 Department of Plant Systems Biology, VIB, Gent, Belgium \\ ${ }^{2}$ Department of Plant Biotechnology and Bioinformatics, Ghent University, Gent, Belgium \\ ${ }^{3}$ Institute of Science and Technology Austria, Klosterneuburg, Austria
}

\section{Edited by:}

Maren Müller, University of

Barcelona, Spain

\section{Reviewed by:}

Inhwan Hwang, Pohang University of Science and Technology, South Korea Ykä Helariutta, University of Helsinki, Finland

\section{*Correspondence:}

Eva Benková, Institute of Science and Technology Austria, Am Campus 1, 3400 Klosterneuburg, Austria e-mail: eva.benkova@psb.vib-ugent.be
As sessile organisms, plants have to be able to adapt to a continuously changing environment. Plants that perceive some of these changes as stress signals activate signaling pathways to modulate their development and to enable them to survive. The complex responses to environmental cues are to a large extent mediated by plant hormones that together orchestrate the final plant response. The phytohormone cytokinin is involved in many plant developmental processes. Recently, it has been established that cytokinin plays an important role in stress responses, but does not act alone. Indeed, the hormonal control of plant development and stress adaptation is the outcome of a complex network of multiple synergistic and antagonistic interactions between various hormones. Here, we review the recent findings on the cytokinin function as part of this hormonal network. We focus on the importance of the crosstalk between cytokinin and other hormones, such as abscisic acid, jasmonate, salicylic acid, ethylene, and auxin in the modulation of plant development and stress adaptation. Finally, the impact of the current research in the biotechnological industry will be discussed.

Keywords: cytokinin, stress, hormonal crosstalk, salicylic acid, abscisic acid

\section{INTRODUCTION}

During their lifespan, plants are exposed to continuously changing environmental conditions and pathogen threats. Various abiotic and biotic stresses, such as heat, cold, drought, high salinity, or pathogen attacks, can severely affect plant development, growth, fertility, and productivity. To survive, plants must be able to react rapidly to various stress signals, activate efficient defense responses, and adapt to new conditions. Plant hormones are key components of these defense and adaptation mechanisms. To mediate the responses and adaptations to stresses, different hormonal pathways are upregulated or downregulated. Modifications in the hormonal abundance and signaling will usually impact on the degree of resistance or susceptibility to the various stresses.

\section{HORMONES AND ABIOTIC STRESSES}

Plants can perceive and respond to environmental changes. For instance, seasonal variations in day/night length or in temperature might directly affect the reproductive cycle, flowering, and fruit set. However, unpredicted changes, such as flooding, extreme temperature, heavy metals, drought, or high salt levels, will be perceived as stress conditions and might have a strongly negative impact on grain yield, grain weight, and plant biomass. Likewise, the root system architecture will adapt in terms of growth and branching as a reaction to different stresses. Among the various stress conditions, salinity and drought are currently the major problems. Saline soils represent a total of 323 million hectares worldwide (Brinkman, 1980), whereas drought affects $1-3 \%$ of the land surface and is predicted to increase to up to $30 \%$ by 2090 (Burke et al., 2006). To cope with these stresses, plants modify the levels of the different phytohormones directly or indirectly. This altered hormonal balance also affects the plant development, with a direct impact on seed development, seed germination, dormancy, and overall plant growth (Finkelstein et al., 2002).

\section{ABSCISIC ACID -THE ABIOTIC STRESS HORMONE}

In response to abiotic stresses, such as drought and salinity, endogenous abscisic acid (ABA) levels increase rapidly, activating specific signaling pathways and modifying gene expression levels (Seki et al., 2002; Rabbani et al., 2003; Kilian et al., 2007; Goda et al., 2008; Zeller et al., 2009). In fact, up to $10 \%$ of protein-encoding genes are transcriptionally regulated by ABA (Nemhauser et al., 2006).

Abscisic acid is one of the most studied phytohormone because of its rapid response and prominent role in plant adaptation to abiotic stresses. In the meantime, the key components of the ABA signaling pathway have been characterized (Sreenivasulu etal., 2007; Cutler etal., 2010; Hirayama and Shinozaki, 2010; Raghavendra etal., 2010; Debnath etal., 2011; Fujita et al., 2011). In Arabidopsis thaliana, the pyrabactin resistance1 (PYR1)/PYR1-LIKE (PYL)/regulatory components of ABA receptor (RCAR) proteins have been proposed as the main intracellular ABA receptors (Ma et al., 2009; Park et al., 2009; Santiago et al., 2009a; Nishimura et al., 2010). Multiple ABA receptor loss-offunction mutants, such as pyr1/pyl1/pyl4, pyr1/pyl1/pyl2/pyl4, and pyr1/pyl1/pyl2/pyl4/pyl5/pyl8 are insensitive to ABA, even at concentrations as high as $100 \mu \mathrm{M}$ (Park et al., 2009; Gonzalez-Guzman et al., 2012). Particularly, the quadruple and sextuple mutants were less sensitive to the $\mathrm{ABA}$-mediated inhibition of seed germination, root growth, stomata closure, and expression of ABA responsive genes (Park et al., 2009; Nishimura et al., 2010; Gonzalez-Guzman 
et al., 2012). Accordingly, PYL5 overexpression resulted in high drought resistance and an enhanced response to ABA (Santiago et al., 2009b).

In the presence of $\mathrm{ABA}$, the PYR/PYL/RCAR proteins form a ternary complex that via direct interaction inhibit clade A protein phosphatase $2 \mathrm{C}(\mathrm{PP} 2 \mathrm{C})$, including ABA-INSENSITIVE 1 (ABI1), ABI2, and hypersensitive to ABA 1 (HAB1) (Nishimura et al., 2007; Santiago et al., 2009a; Szostkiewicz et al., 2010). Similarly to the receptor mutants, mutants in the PP2C activity, such as abil-1, are also insensitive to ABA (Fujii and Zhu, 2009; Cutler et al., 2010). PP2C repression activates downstream targets, such as the protein kinases belonging to the sucrose non-fermenting 1-related subfamily2 SnRK2.2/D, SnRK2.3/I, and SnRK2.6/OST1/E, which trigger ABA-dependent gene expression and signaling (Umezawa et al., 2009; Vlad et al., 2009). Accordingly, the snrk2.2/snrk2.3/snrk2.6 triple mutant is highly insensitive to ABA and severely affects plant growth and seed yield (Fujii and Zhu, 2009).

\section{CYTOKININ IN ABIOTIC STRESS RESPONSES}

Besides ABA, other hormonal pathways, including cytokinin (CK), are activated when a plant is exposed to stress. The CK-dependent modulation of stress responses has been studied at various levels. The alteration of endogenous CK levels in reaction to stress suggests that this hormone is involved in stress responses. For instance, in response to drought, the in planta concentration and transport of trans-zeatin riboside decreases drastically, whereas the ABA levels increase (Hansen and Dörffling, 2003; Davies et al., 2005). Interestingly, when the partial root zone-drying approach was applied, the CK concentration decreased, not only in roots, but also in leaves, buds, and shoot tips, along with increased ABA levels (Stoll et al., 2000; Kudoyarova et al., 2007). These observations demonstrate that the local stress exerted on the root might trigger changes in the CK levels in various plant organs, including the shoot, and, consequently, in developmental processes, such as the apical dominance (Hansen and Dörffling, 2003; Schachtman and Goodger, 2008). Typically, reduced CK levels would enhance the apical dominance, which, together with the ABA regulation of the stomatal aperture, aids to adapt to drought stress.

The negative CK-regulatory function in plants exposed to drought has been demonstrated in genetic studies in which the endogenous CK levels were modified, either by loss of the biosynthesis genes isopentyl transferase (IPT) or by overexpression of cytokinin oxidase (CKX)-encoding degradation genes (Werner et al., 2010; Nishiyama et al., 2011; Wang et al., 2011b). A reduced CK content in the ipt1/ipt3/ipt5/ipt7 quadruple and ipt8 single mutants or overexpression of CKX1 and its homologs correlates with an increased resistance to both salt and drought stresses.

In agreement with the increased abiotic stress resistance at low CK levels, mutants lacking the functional CK receptors are more resistant to abiotic stresses (Tran et al., 2007; Jeon et al., 2010; Kang et al., 2012). For example, the Arabidopsis histidine kinase $(A H K)$ loss-of-function mutants $a h k 2 / a h k 3$ and $a h k 3 / a h k 4$ were significantly more resistant to freezing temperatures than the wild type (Jeon et al., 2010). Similarly, all ahk single and multiple mutants, with the exception of ahk4, showed an enhanced resistance to dehydration (Kang et al., 2012). Furthermore, like the
CK-metabolic mutants ipt1/ipt3/ipt5/ipt7, ipt8, and the CKX1overexpressing plants, the ahk mutants affected dramatically the ABA sensitivity (Tran et al., 2007) and were hypersensitive to ABA treatments.

Downstream of the AHK receptors, the Arabidopsis histidine phosphotransfer (AHP) proteins mediate stress signaling (Hwang and Sheen, 2001; Hutchison et al., 2006; To and Kieber, 2008; Hwang et al., 2012). AHP proteins translocate into the nucleus and activate the type-B Arabidopsis response regulator (ARR) factors that trigger the transcription of specific genes in response to CK. A negative feedback loop is provided by type-A ARRs that inhibit the activity of type-B ARRs by a still unknown mechanism (Figure 1). Of all ARRs, type-A ARRs are the only ones of which the expression is altered under stress, e.g., ARR5, ARR6, ARR7, and $A R R 15$ are upregulated upon cold stress (Jeon et al., 2010; Jeon and Kim, 2013); ARR5, ARR7, ARR15, and type-C ARR22 are upregulated in response to dehydration (Kang et al., 2012); and $A R R 5$ expression increases in response to salt stress (Mason et al., 2010). Stimulation of ARR5, ARR6, ARR7, and ARR15 expression in response to cold stress requires the activity of several components of the CK signaling pathway, including AHP2, AHP3, and AHP5, and also ARR1 (Jeon and Kim, 2013). Likewise, in response to salt stress, ARR5 upregulation depends on ARR1 and ARR12 (Mason et al., 2010). Furthermore, the negative regulatory role of AHP2, AHP3, and AHP5 during drought stress has been described recently (Nishiyama et al., 2013).

Despite the clear indications that CK and the CK signaling components function in stress responses (Hwang et al., 2012), the high degree of redundancy in the CK signaling pathway, including three CK receptors, six AHPs, 10 type-A ARRs, and 11 type-B ARRs, makes it difficult to dissect the role of each specific component (Hwang et al., 2012). Interestingly, although CK levels are reduced, the type-A ARRs that belong to the early CK-responsive genes are upregulated (Jeon et al., 2010; Mason et al., 2010; Kang et al., 2012; Jeon and Kim, 2013). Furthermore, a quadruple typeA ARR loss-of-function mutant arr3/arr4/arr5/arr6 is resistant to salt stress, which is unexpected because to type-A ARRs act as CK signaling repressors (Mason et al., 2010). These observations imply that in stress responses the role played by the CK signaling pathway is more complex. In this context, AHKs might function as stress sensors that would activate the CK signaling pathway independently of CK levels (Urao et al., 1999; Tran et al., 2007; Jeon et al., 2010). In fact, another member of the histidine kinase family, AHK1, is able to sense and transduce changes in osmolarity to trigger downstream signaling pathways (Urao et al., 1999; Tran et al., 2007). However, unlike the CK receptors AHK2, $\mathrm{AHK} 3$, and AHK4, AHK1 positively regulates stress responses. Thus, it remains to be elucidated whether AHK2, AHK3, or AHK4 can sense abiotic stresses independently of CK, or whether AHK1 might crosstalk with a downstream CK signaling cascade.

Besides core components of the CK transduction cascade, downstream targets in stress responses have been disclosed as well. The cytokinin response factor (CRF) transcription factors of the APETALA2 (AP2) family have been identified as early $\mathrm{CK}$ response genes of which the expression is rapidly induced after CK application (Rashotte et al., 2006). Interestingly, the CRF6 homolog is also highly responsive to various abiotic stress 


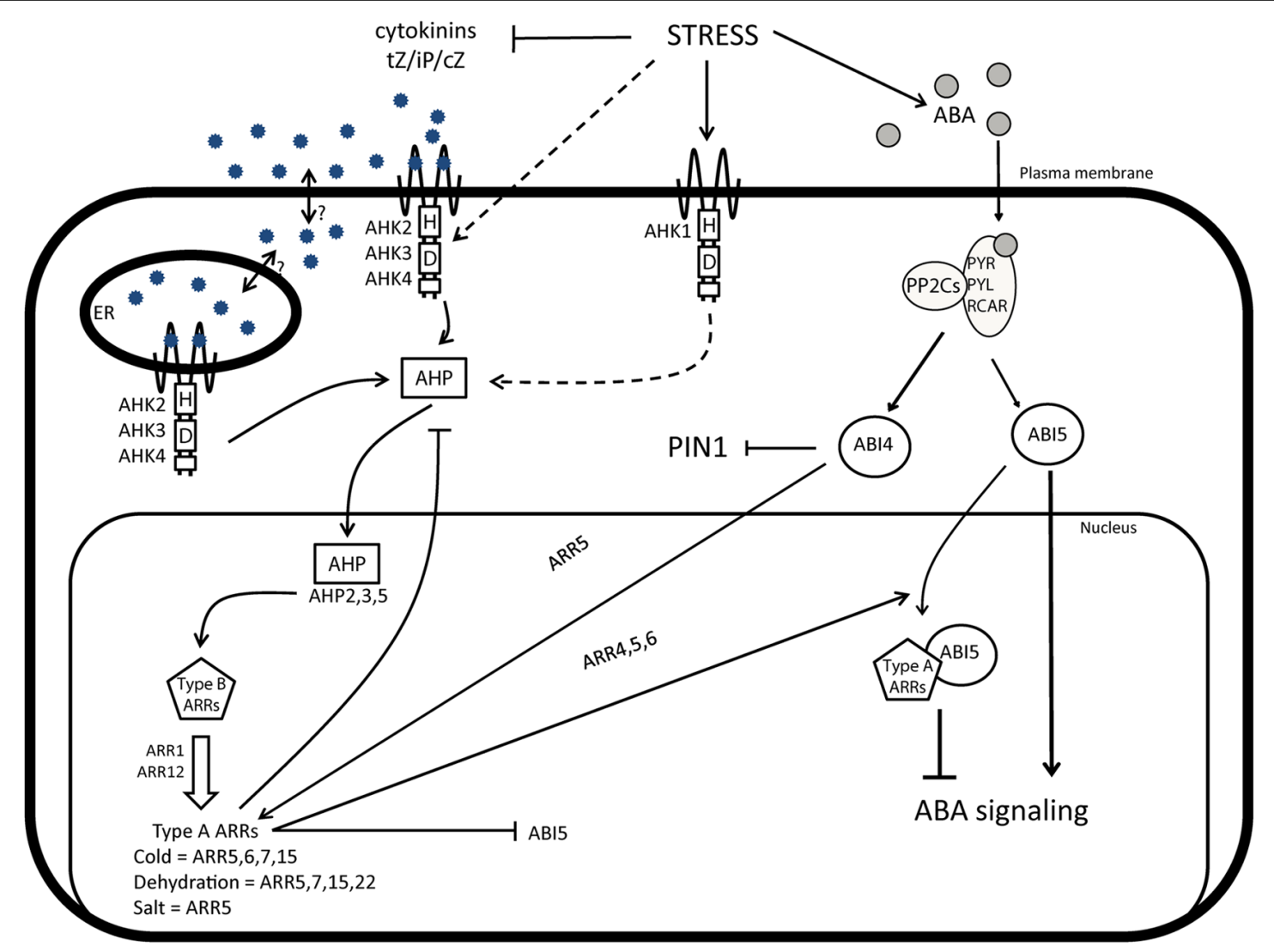

FIGURE 1 | CK and crosstalks during abiotic stress responses. Under non-stress conditions, CK activates signaling mediated through AHK receptors, AHPs, and type-B response regulators ARRs. Type-B ARRs stimulate the expression of the early $C K$ response genes, including type-A $A R R$ genes that provide a negative feedback loop of the CK signaling. Besides this negative feedback loop, type-A ARRs also repress the expression of $A B I 5$ and interfere with the ABA signaling, through the physical interaction with $A B I 5$. In response to stress, $A B A$ levels increase and, simultaneously, CK levels decrease. The recognition of ABA by the receptors PYR/PYL/RCAR promotes the interaction with $\mathrm{PP} 2 \mathrm{C}$ proteins that will activate downstream responses through signaling components including $A B \mid 5$ and $A B \mid 4$. At the same time, $A B A$ interferes with the activity of $\mathrm{CK}$ and auxin and via $\mathrm{ABI} 4$ attenuates the expression of the PIN1 auxin efflux carrier and enhances the transcription of the CK signaling repressor ARR5. Interestingly, type-A ARRs, such as ARR5, are upregulated, despite the low CK levels, probably because of the indirect activation of the CK signaling pathway by alternative receptors of the histidine kinase family, such as AHK1. treatments (Zwack et al., 2013) and, recently, its regulatory role has been characterized in leaf senescence control (Zwack et al., 2013).

\section{HORMONAL CROSSTALKS AND ABIOTIC STRESS RESPONSES}

The altered ABA sensitivity in plants with modified CK levels and signaling (Tran et al., 2007; Werner et al., 2010; Nishiyama et al., 2011; Wang etal., 2011b) hints at a crosstalk between ABA and CK. Interestingly, ARR4, ARR5, and ARR6 have been found to interact with ABI5 and also to regulate its expression levels. ABI5 is a basic leucine zipper protein that positively regulates the ABA signaling. The interaction with type-A ARRs attenuates the ABI5 activity and suppresses the ABA signaling (Figure 1; Wang et al., 2011b). Thus, type-A ARRs might, in addition to their regulation of the CK signaling, also control ABA signaling.

New insights into the ABA-CK crosstalk have been gained from the functional analysis of ABI4 (Shkolnik-Inbar and BarZvi, 2010), that belong to the AP2 family of transcription factors. Similar to ABI5, ABI4 is also a positive regulator of the ABA signaling (Wind etal., 2013) and of the type-A ARR5 expression that represses the CK signaling. Simultaneously, ABI4 attenuates the expression of the PIN-FORMED 1 (PIN1) gene, an auxin efflux carrier that is an essential component of the polar auxin transport machinery (Shkolnik-Inbar and Bar-Zvi, 2010). Thus, ABI4 might represent an important crosstalk point on the interface of ABA, CK, and auxin pathways (Figure 1), in agreement with observations demonstrating that both the levels of CK and auxin, as well as of the PIN3 and PIN7 auxin efflux carriers, are suppressed when the ABA level increases (Hwang and Sheen, 2001; Wang et al., 2011a). Altogether, the strong impact of stress on plant development might result from the combined activities of several hormonal pathways, such as $\mathrm{ABA}$ and development-related hormones, such as $\mathrm{CK}$ and auxin.

The hormonal pathway of ethylene (ET) contributes also to the complexity of the hormonal network underlying plant responses to stresses. ET has been studied both in a developmental and stress context (Cary et al., 1995; Chae et al., 2003; Dietz et al., 2010; Kushwah et al., 2011; Beguerisse-Díaz et al., 2012; 
Vanstraelen and Benková, 2012; Zhai et al., 2013) and, recently, its role as a negative regulator of freezing tolerance has been demonstrated (Shi et al., 2012). The ET activity in stress responses is mediated by the downstream transcription factor of the ET signaling cascade, ethylene-insensitive 3 (EIN3). EIN3 suppresses the expression of the $C$-repeat/dehydration response element-binding factor 1 (CBF1), $C B F 2$, and $C B F 3$ genes, which mediate the response to cold stress, and also of the CK signaling repressors ARR5, ARR7, and ARR15 by direct binding to their promoters (Shi et al., 2012). Although ET interferes with the CK signaling output, its pathway is also affected by CK. Indeed, CK stabilizes 1-aminocyclopropane-1-carboxylate synthase 5 (ACS5) and ACS9 (Vogel et al., 1998; Chae et al., 2003; Hansen et al., 2009) that convert $S$-adenosyl-methionine to 1-aminocyclopropane-1carboxylic acid (ACC), the rate-limiting step in the ET biosynthesis. This stabilization might lead to an ET accumulation and, consequently, affect plant growth processes, such as root growth (Cary et al., 1995; Rưžička et al., 2007). The complexity of the hormonal regulatory network underlying stress responses has been suggested (Lehotai et al., 2012) by the activation of both CK and ET signaling in response to selenite-induced stress by means of the ARR5 and ACS8 markers and decrease in the auxin levels.

Interestingly, the CK-ET and CK-ABA interactions exhibit tissue-specific features. CK treatments have been demonstrated to promote the ABA accumulation in shoots, but not in roots, in contrast to ET that accumulates predominantly in roots in response to high CK levels (Žd'árská et al., 2013).

\section{PLANT HORMONES IN RESPONSES TO BIOTIC STRESSES}

Hormones also tightly regulate plant responses against pathogens. The networks that control the immune responses in plants are highly complex and have been extensively reviewed (Feys and Parker, 2000; Broekaert et al., 2006; Robert-Seilaniantz et al., 2007; Nishimura and Dangl, 2010). The best characterized hormones that play a role in pathogen response/defense are salicylic acid (SA), jasmonate (JA), and ET. Depending on the lifestyle of the pathogens, a different response will be triggered by the plant. Against biotrophic pathogens, the resistance largely depends on SA-mediated responses and the principal defense strategy is programmed cell death (apoptosis) that restricts the biotrophic pathogen to the infection site, preventing its proliferation, and further spreading in the plant (Dangl and Jones, 2001; Jones and Dangl, 2006; Nishimura and Dangl, 2010; An and Mou, 2011). In contrast, for necrotrophic pathogens that feed on death tissue only, cell death is beneficial. These pathogens induce defense responses that depend on JA and ET to prevent cell death and that trigger the secretion of antimicrobial compounds and the accumulation of proteins with antimicrobial and antifungal activity, such as plant defensins (Overmyer et al., 2000; Andi et al., 2001; Alonso and Stepanova, 2004; Broekaert et al., 2006; Balbi and Devoto, 2008; Fonseca et al., 2009; Gfeller et al., 2010). Because of their difference in the nature of the defense strategy, the JA-ET interaction tends to antagonize the SA responses (Peña-Cortés et al., 1993; Doares et al., 1995; Petersen et al., 2000; Kloek et al., 2001), so that the stress-activated JA-ET signaling might suppress the SA-mediated resistance and vice versa. However, these two pathways might synergistically interact and be considered a fine-tuning mechanism to respond to biotic stresses (Cui et al., 2005; Mur et al., 2006; Truman et al., 2007).

Once the pathogens or microbes have gained access to the plant tissues, they are sensed in each cell by pattern recognition receptors present in the plasma membrane of the host plant cells and bind to microbe-associated molecular patterns (MAMPs; Gómez-Gómez, 2004; Zipfel et al., 2006), the mechanism designated basal resistance or MAMP-triggered immunity (MTI). To overcome MTI, pathogens secrete effectors into the plant cytosol. In this manner, these proteins interfere with the plant immune responses (Chisholm etal., 2006) and modify the host proteins to evade detection and, hence, enhance their virulence, which is referred to as effector-triggered susceptibility. However, the coevolution of plants and microbes has led to the acquisition of the $\mathrm{R}$ proteins that specifically recognize these pathogen effectors or avirulence (avr) proteins in a characterized response known as gene-for-gene resistance or effector-triggered immunity (ETI) (Flor, 1971). This specific resistance response is noticeable by localized cell death at the infection site and is known as the hypersensitive response (Hammond-Kosack and Jones, 1996; Greenberg and Yao, 2004).

\section{SALICYLIC ACID IN BIOTIC STRESSES}

During the hypersensitive response, different signal transduction pathways are activated. Tissues distal from the infection site develop an enhanced broad-spectrum resistance to secondary infections that is the systemic acquired resistance (SAR; Yarwood, 1960; Ross, 1961). Before SAR is triggered in remote leaves, SA, which is crucial for this defense strategy, accumulates (Malamy et al., 1990). When transgenic Arabidopsis plants express the bacterial SA hydroxylase gene $n a h G$ that disables the SA accumulation because of its fast turnover to catechol, they cannot develop SAR and induce the pathogen resistance $(P R)$ gene expression (Gaffney et al., 1993; Delaney et al., 1994). Furthermore, lipid transfer proteins and SA-binding proteins might be involved in the SA accumulation-triggering signaling in SAR (Park et al., 2007). The non-expresser PR1 (NPR1) protein acts downstream of SA and transduces the signal to promote the $P R$ gene expression (Durrant and Dong, 2004). During SAR induction, an oxidative burst occurs, followed by an increase in antioxidants to neutralize the harmful effects of reactive oxygen species. This reducing environment can then convert NPR1 from its inactive oligomeric form into its activated monomeric form that can be transported from the cytosol to the nucleus and activate transcription factors (Kanzaki et al., 2003; Mou et al., 2003), via protein-protein interactions between NPR1 and the TGACG sequence-specific (TGA) transcription factors (Zhang et al., 1999).

\section{JASMONIC ACID AND ETHYLENE IN BIOTIC STRESSES}

The defense response to an attack by necrotrophic pathogens and chewing insects is mediated through the JA pathway that commonly acts together with ET to mount a coordinated defense response. One of the best characterized components of the JA signaling pathway is the coronatine insensitive (COI1) receptor (Devoto etal., 2002; Xu et al., 2002). COI1 is part of the Skp1/Cullin/F-box (SCF) E3 ubiquitin-ligase protein degradation complex $\mathrm{SCF}^{\mathrm{COI} 1}$. High JA levels promote the interaction of the $\mathrm{SCF}^{\mathrm{COI} 1}$ complex with the JA ZIM (JAZ) domain repressors 
and activate the transcription of JA-responsive genes. The coil mutants that lack the functional JA receptor are more susceptible to infections by insects and necrotrophic pathogens, such as Botrytis cinerea, Pythium irregulare, or Alternaria brassicicola (van Wees etal., 2003; Adie etal., 2007; Ferrari et al., 2007; Ye et al., 2012). Likewise, mutations that stabilize the JAZ proteins (JAZ1 $\triangle 3 \mathrm{~A})$ increase the susceptibility against herbivores, such as Spodoptera exigua (Chung et al., 2008), further supporting the significance of a functional JA signaling pathway in plant defense responses.

The JA-mediated responses against pathogens is strengthened by the ET activity. Ethylene is perceived in plants by the receptors ethylene resistant1 (ETR1), ETR2, ethylene-insensitive4 (EIN4), ethylene response sensor1 (ERS1), and (ERS2) that belong to a histidine kinase family (Bleecker et al., 1988; Chang et al., 1993; Hua et al., 1995, 1998; Sakai et al., 1998). Mutations in these receptors not only confer ET insensitivity, but also increase susceptibility to necrotrophic pathogens (Geraats et al., 2003). Downstream from these receptors, the Raf-like kinase constitutive triple response 1 (CTR1) is active, which is a negative ET response regulator. In the presence of ET, the CTR1 repression activates EIN2 (Guzmán and Ecker, 1990; Kieber et al., 1993; Chao et al., 1997) and, subsequently, stimulates the EIN3/EIL-like (EIL) transcription factors, whereas mutations in EIN2 confer ET insensitivity, in addition to an increased susceptibility to necrotrophic pathogens (Geraats et al., 2003).

Although both JA and ET contribute jointly to the plant's fight against pathogen attacks, the molecular mechanisms of their crosstalk are not well understood, but new insights into the molecular mechanisms underlying their interactions have been provided (Zhu et al., 2011). The JAZ repressors of the JA signaling interact physically with the EIN3/EIL1 transcription factors and attenuate their ability to activate genes (Zhu et al., 2011). This interaction has a striking developmental impact, because it enables JA to contribute to the ET response regulation. Thus, besides the classical mechanism in which ET induces the EIN3/EIL1 stabilization (Guo and Ecker, 2003; Potuschak etal., 2003), EIN3/EIL1 is released from repression by JA through JAZ degradation, thereby triggering ET responses (Zhu et al., 2011).

The hormonal interplay between pathways that depend on JA-ET and SA is particularly important when plants are exposed to multiple pathogens of both biotrophic and necrotrophic types. Under such conditions, an effective defense requires only one of these pathways, but still they need to be tightly balanced with each other. This very complex crosstalk between JA and SA has been reviewed thoroughly (see Beckers and Spoel, 2006; Thaler et al., 2012).

\section{CYTOKININ AND ITS CROSSTALK WITH SALICYLIC ACID}

One of the first indications on the involvement of CK in biotic stress came from tobacco (Nicotiana tabacum) plants in which the S-adenosyl-homocysteine hydrolases (SAHHs) were downregulated. Originally, SAHHs have been studied in mammals because of their role in the regulation of transmethylation and mRNA 5' capping during viral replication (De Clercq, 1998). Interestingly, the tobacco plants with low $S A H H$ expression not only exhibited an enhanced resistance against the tobacco mosaic virus
(TMV), cucumber mosaic virus, potato virus $\mathrm{X}$, and potato virus $\mathrm{Y}$ (Masuta et al., 1995), but also increased CK levels and CK-related developmental defects.

In attacked plants, the CK levels are coregulated with the SA levels (Kamada et al., 1992; Sano et al., 1994, 1996; Masuta et al., 1995). Tobacco plants that overexpressed the Ras-related small GTP-binding protein 1 (RGP1)-encoding gene exhibited higher levels of SA and of the acidic pathogenesis-related $1(P R-1 a)$ gene than those of wild-type plants, in correlation with an enhanced resistance against TMV infection. Interestingly, these transgenic plants also showed phenotypes typical for a high endogenous CK activity, such as reduced apical dominance and increased tillering (Kamada et al., 1992), as was, indeed, confirmed later (Sano et al., 1994, 1996). Furthermore, in both wild-type and $R G P 1$-overexpressing plants, the CK perception inhibited by the use of the competitive inhibitor 2-chloro-4-cyclohexylamino-6ethylamino-s-triazine interfered with the expression of the SAdependent $P R-1 a$ and the basic JA-dependent $P R-1$ after wounding (Sano et al., 1996), thereby suggesting that CK contributes to the defense responses mediated by SA and JA.

As mentioned, the recognition of the pathogen Avr effector proteins by the resistance $(\mathrm{R})$ proteins is an important part in plant defense responses. This interaction triggers ETI, which is characterized by the production of SA and the subsequent induction of $P R$ genes and SAR. A dominant-positive mutant of the coiled-coil nucleotide-binding leucine-rich-repeat (CC-NB-LRR) protein UNI ( uni-1D) that constitutively activates ETI (Igari et al., 2008) exhibits an enhanced expression of $P R-1, P R-5$, and of the type-A ARR CK-signaling repressors and increased endogenous CK levels, with phenotypic alterations typical for high CK activity as a consequence (Figure 2; Igari et al., 2008). In uni-1D plants, CK levels decreased by the CKX1 induction reduces both the $P R-1$ and of type-A $A R R$ gene expression. However, in these uni-1D plants, overexpression of the bacterial SA hydroxylaseencoding nah $G$ gene prevents SA accumulation and interferes with the $P R-1$ expression, but without effect on the type-A $A R R$ gene induction and the CK-like phenotypes (Igari et al., 2008). A similar CK-related phenotype has been observed in the knockdown mutant rin $4 K-D$ of the resistance to Pseudomonas syringae pv. maculicola (RPM1)-interacting protein 4 (RIN4), which is a negative regulator of $\mathrm{R}$ proteins. In rin $4 K-D$ plants, the $\mathrm{R}$ proteins Resistant to P. syringae 2 (RPS2) and RPM1 are constitutively active and trigger ETI, whereas both $P R-1$ and ARR5 transcript levels are upregulated and the phenotypic alterations are typical for high CK activity (Figure 2; Igari et al., 2008).

Another indication of the crosstalk between CK and SA has emerged from the characterization of the CRF 5 (Figure 2; Liang et al., 2010). Indeed, the CRF5 expression is upregulated in response to Pseudomonas syringae pv. tomato DC3000 (Pst DC3000) and the transcript levels of SA-induced $P R-1, P R-3$, $P R-4$, and $P R-5$ are increased in the CRF5-overexpressing lines (Rashotte et al., 2006; Cutcliffe et al., 2011). This crosstalk mechanism between CK and SA has been elucidated (Choi et al., 2010) by showing that pretreatment of Arabidopsis plants with CK significantly increased the resistance against Pst DC3000 infection. Correspondingly, mutants defective in CK perception and signaling, such as $a h k 2 / a h k 3$ and $\operatorname{arr} 2$, or plants with reduced 


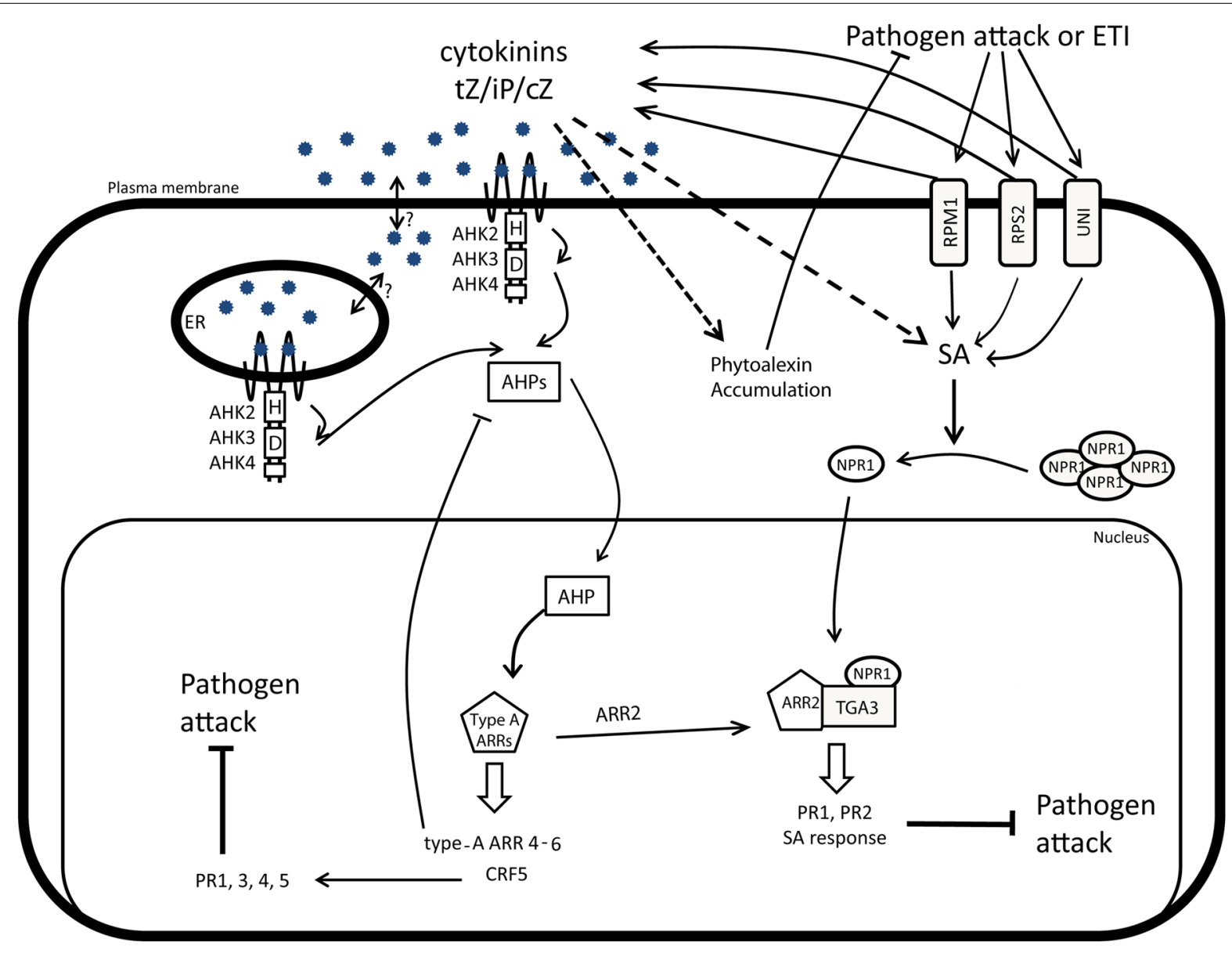

FIGURE 2 | CK and hormonal crosstalks during biotic stress responses. Pathogen attacks stimulated by PAMP-triggered immunity (PTI) and effector-triggered immunity (ETI) correlate with a dramatic production of SA and $\mathrm{CK}$. The accumulation of $\mathrm{CK}$ will induce the production and accumulation of phytoalexins in a SA-independent manner and also enhance the SA-dependent immunity. In response to pathogens, NPR1 monomerizes and translocates to the nucleus where it interacts with TGA3. The NPR1-TGA3 activity is further regulated through interaction with the type-B ARR2 response regulator, a component of the $\mathrm{CK}$ signaling pathway. The

TGA3-NPR1-ARR2 complex is required to induce the SA-mediated resistance and to trigger the expression of $P R 1$ and PR2. High CK levels, induced after pathogen attacks, can activate the CRF5-mediated branch of the CK signaling pathway and contribute to the regulation of the $P R 1, P R 3, P R 4$, and $P R 5$ expression. endogenous CK levels, such as 35S::CKX2 and 35S::CKX4, were more susceptible to Pst DC3000. In contrast, the plant resistance to Pst DC3000 was enhanced by high endogenous CK levels due to overexpression of the CK biosynthesis (IPT) genes or by $\mathrm{CK}$ signaling promoted by increased $A R R 2$ expression (Choi et al., 2010). Therefore, CK has been proposed to affect priming, a defense-related response activation and might assist plants to cope with infections through the induced SA signaling and increased PR expression levels (Igari et al., 2008; Choi et al., 2010; Liang et al., 2010). This scenario is strongly supported by the findings that ARR2 interacts directly with the SA response factor TGA3, which binds the promoter regions of $P R-1$ and $P R-2$, and that this interaction is essential for the enhanced resistance of the 35S::ARR2 lines. Altogether, both the SA-triggered translocation of NPR1 into the nucleus and the formation of a complex with TGA3-ARR2 are seemingly necessary for the development of a full SA-mediated defense response (Choi et al., 2010, 2011). The impact of CK on the plant defense has been characterized in the
Pst DC3000-Arabidopsis interaction model with the SA induction deficient 2 (sid2) mutant that fails to accumulate SA (Naseem et al., 2012). The increased susceptibility of sid2 toward Pst DC3000 can only be partially recovered by CK treatment (Naseem et al., 2012), thereby supporting that $\mathrm{CK}$ treatments enhance the immunity in an SA-dependent manner (Naseem and Dandekar, 2012).

Recently, the CK-promoted protection against pathogenic infections has been suggested to be involved in SA-independent mechanisms (Großkinsky et al., 2011). In the P. syringae pv. tabacitobacco interaction model, higher CK levels before infection increase the resistance of tobacco against $P$. syringae pv. tabaci and this resistance depends on increases phytoalexin levels, such scopoletin and capsidiol, which accumulate in the presence of CK (Großkinsky et al., 2011). Thus, the mechanism underlying the CK-mediated resistance of tobacco differs from that in Arabidopsis that is based on an SA-dependent transcriptional control. In the solanaceous plant species, CK appears to promote primary defense responses through an increase of the phytoalexin-pathogen ratio 
in the early infection phases that then efficiently restricts the pathogen development.

\section{CYTOKININ AND ITS CROSSTALK WITH JASMONIC ACID}

Even though there is not much evidence for an interplay between JA and CK, these hormonal pathways might be linked directly (Ueda and Kato, 1982; Dermastia et al., 1994; Sano et al., 1996) and their interaction might be antagonistic (Naik et al., 2002; Stoynova-Bakalova et al., 2008). Typically, in wounded plants, the JA levels increase significantly, whereas the SA levels remain unchanged, but both $\mathrm{CK}$ applications and high endogenous CK levels accelerate the defense response to reach a faster maximum release of JA and methyl jasmonate (MeJA) than in control plants (Sano et al., 1996; Dervinis et al., 2010). In potato (Solanum tuberosum), JA treatments can induce the accumulation of CK ribosides (Dermastia et al., 1994), whereas they might strongly inhibit the CK-induced callus growth (Ueda and Kato, 1982). These observations hint at a very complex and unexplored interplay, in which the outcome probably depends not only on the CK-JA ratio, but also that of other hormones as well.

\section{CYTOKININ AND ITS CROSSTALK WITH AUXIN}

Crosstalk between CK and auxin has been widely studied over the years, particularly in a developmental context in which their interaction is primarily antagonistic (Bishopp et al., 2011; Vanstraelen and Benková, 2012), although a number of recent studies undoubtedly point toward a role of auxin in stress responses. Various pathogens can produce auxins or modulate auxin levels in planta to enhance the plant susceptibility to infection (Chen et al., 2007; An and Mou, 2011). In Arabidopsis plants lacking the functional RPS2 gene, the expression of the P. syringae type III effector AvrRpt2 decreased the resistance against Pst DC3000, and also show altered auxin levels and auxin-related phenotypes (Chen et al., 2007). This direct correlation between sensitivity and auxin levels implies that auxin promotes plant susceptibility. Also, a recent study in which $P R 1$ was used as a marker gene in the Pst DC3000-Arabidopsis interaction revealed that, whereas the immunity was positively promoted by $\mathrm{CK}$ and SA, it was negatively regulated by auxin, JA, and ABA (Naseem etal., 2012). Interestingly, the positive effect of CK pretreatments on the plant immunity can be repressed by a combined CK and auxin treatment (Naseem et al., 2012). Based on this evidence, CK and auxin might play a highly possible antagonistic role in plant defense responses, but the specific mechanisms that modulate this crosstalk are still unknown.

A model for the CK-auxin interplay in plant defense has been proposed (Naseem and Dandekar, 2012). After infection, pathogens will modulate the auxin levels and the signaling that will diminish the responses mediated by SA and CK, whereas CK pretreatments will prevent the auxin-based susceptibility, due to the known effect of CK on auxin transport and signaling.

\section{CONCLUSIONS AND FUTURE PERSPECTIVES}

Nowadays, one of the major objectives of plant biologists is to improve plant performances under less favorable environmental conditions. By enhancing plant defense responses against biotic and abiotic stress, non-cultivable land might be used, the losses due flooding and infections be decreased, and the amount of applied fertilizers and pesticides in the fields be reduced. However, because the crosstalk between stress-related and developmental hormones is largely unknown, and uncharacterized, usually unforeseen problems occur when the stress resistance is modified. Ideally, plants with enhance resistance to stress or pathogen attacks should not be affected in growth or developmentally hampered. In this context, it is crucial to understand the hormonal crosstalks underlying plant responses to various stresses, because the modification of one single hormonal pathway will very probably alter the activity of other hormonal pathways as well.

The complexity of the impact of hormones on the resistance to stress can be nicely illustrated with examples of plants with altered CK levels. Due to the importance of CK in stress responses, several genes involved in the regulation of CK levels have been proposed as possible targets to enhance stress resistance, such as the IPT and CKX genes (Werner et al., 2010; Nishiyama et al., 2011; Wang et al., 2011b). However, the benefit of the stress-tolerant phenotype of the IPT loss-of-function mutants or of $C K X$-overexpressing plants was counteracted by developmental defects caused by low bioactive CK levels, such as N6-( $\Delta 2$-isopentenyl)adenine and trans-zeatin (Nishiyama et al., 2011). To overcome this drawback, it is necessary to control the CK activity either in an organ or in a tissue-specific manner, an approach that has already been used in several species (McCabe et al., 2001; Sýkorová et al., 2008; Ghanem et al., 2011; Qin et al., 2011). For instance, as a consequence of downregulated CK levels in root tissues only (Werner et al., 2010), root length, branching, and biomass increased and the plants were also more resistant to abiotic stress treatments, such as severe drought or heavy metal contaminations (Werner et al., 2010). Furthermore, modulation of CK-mediated defense to stress might at the same time attenuate the input provided by other signaling pathways, such as ABA (Wang et al., 2011b). A reduced CK content leads to a decrease in ABA content and hypersensitivity to ABA treatments (Nishiyama et al., 2011), in contrast to the stressed plants in which the ABA levels are upregulated (Stoll et al., 2000; Hansen and Dörffling, 2003; Kudoyarova et al., 2007). Correspondingly, overexpresssion of IPT8 results in insensitivity to ABA treatments and prevents the induction of $A B I 1$ and $A B I 5$ in seedlings (Wang et al., 2011b). These examples clearly show that a good knowledge of the molecular mechanisms underlying the hormone-mediated responses and of the mutual communication among hormonal pathways might be very rewarding in the targeted modulation of specific hormonal pathways and, hence, in the effective plant adaptation to concrete environmental conditions.

Extended studies on the genes that mediate the crosstalk between CK and other developmental and stress-related hormones might identify novel targets for the stress tolerance improvement of crop species. Importantly, the identification of molecular components and mechanisms that mediate the phytohormonal interplay might enable us to dissect the stress-related from the developmental functions.

Finally, to increase the plant resistance against various stresses, new alternative approaches should take in account the specific features of the plant species and the distinct mechanisms that underlay their stress responses (Choi et al., 2010; Großkinsky et al., 2011). A nice example of such a strategy is the enhanced 
drought stress tolerance of alfalfa (Medicago sativa) by means of CK-overproducing Sinorhizobium meliloti without impact on nitrogen fixation (Xu et al., 2012).

\section{ACKNOWLEDGMENTS}

We would like to thank Annick Bleys and Martine De Cock for their help in preparing the manuscript. This work was supported by the European Research Council with a Starting Independent Research grant (ERC-2007-Stg-207362-HCPO) and the Central European Institute of Technology (project CZ.1.07/2.3.00/20.0043). José A. O'Brien is a postdoctoral fellow of the Research FoundationFlanders. We apologize that, due to space restrictions, the scientific contributions of only a limited number of original articles could be cited and discussed.

\section{REFERENCES}

Adie, B. A. T., Pérez-Pérez, J., Pérez-Pérez, M. M., Godoy, M., Sánchez-Serrano, J.-J., Schmelz, E. A., et al. (2007). ABA is an essential signal for plant resistance to pathogens affecting JA biosynthesis and the activation of defenses in Arabidopsis. Plant Cell 19, 1665-1681. doi: 10.1105/tpc.106.048041

Alonso, J. M., and Stepanova, A. N. (2004). The ethylene signaling pathway. Science 306, 1513-1515. doi: 10.1126/science.1104812

An, C., and Mou, Z. (2011). Salicylic acid and its function in plant immunity. J. Integr. Plant Biol. 53, 412-428. doi: 10.1111/j.1744-7909.2011.01043.x

Andi, S., Taguchi, F., Toyoda, K., Shiraishi, T., and Ichinose, Y. (2001). Effect of methyl jasmonate on harpin-induced hypersensitive cell death, generation of hydrogen peroxide and expression of PAL mRNA in tobacco suspension cultured BY-2 cells. Plant Cell Physiol. 42, 446-449. doi: 10.1093/pcp/pce056

Balbi, V., and Devoto, A. (2008). Jasmonate signalling network in Arabidopsis thaliana: crucial regulatory nodes and new physiological scenarios. New Phytol. 177, 301-318. doi: 10.1111/j.1469-8137.2007.02292.x

Beckers, G. J. M., and Spoel, S. H. (2006). Fine-tuning plant defence signalling: salicylate versus jasmonate. Plant Biol. (Stuttg.) 8, 1-10. doi: 10.1055/s-2005872705

Beguerisse-Díaz, M., Hernández-Gómez, M. C., Lizzul, A. M., Barahona, M., and Desikan, R. (2012). Compound stress response in stomatal closure: a mathematical model of ABA and ethylene interaction in guard cells. BMC Syst. Biol. 6:146. doi: 10.1186/1752-0509-6-146

Bishopp, A., Benková, E., and Helariutta, Y. (2011). Sending mixed messages: auxin-cytokinin crosstalk in roots. Curr. Opin. Plant Biol. 14, 10-16. doi: 10.1016/j.pbi.2010.08.014

Bleecker, A. B., Estelle, M. A., Somerville, C., and Kende, H. (1988). Insensitivity to ethylene conferred by a dominant mutation in Arabidopsis thaliana. Science 241 1086-1089. doi: 10.1126/science.241.4869.1086

Brinkman, R. (1980). "Saline and sodic soils," in Land Reclamation and Water Management: Developments, Problems, and Challenges, ILRI Publication No. 27 (Wageningen: International Institute for Land Reclamation and Improvement), 62-68.

Broekaert, W. F., Delauré, S. L., De Bolle, M. F. C., and Cammue, B. P. A. (2006). The role of ethylene in host-pathogen interactions. Annu. Rev. Phytopathol. 44, 393-416. doi: 10.1146/annurev.phyto.44.070505.143440

Burke, E. J., Brown, S. J., and Christidis, N. (2006). Modeling the recent evolution of global drought and projections for the twenty-first century with the Hadley Centre climate model. J. Hydrometeorol. 7, 1113-1125. doi: 10.1175/JHM544.1

Cary, A. J., Liu, W., and Howell, S. H. (1995). Cytokinin action is coupled to ethylene in its effects on the inhibition of root and hypocotyl elongation in Arabidopsis thaliana seedlings. Plant Physiol. 107, 1075-1082. doi: 10.1104/pp.107.4.1075

Chae, H. S., Faure, F., and Kieber, J. J. (2003). The eto1, eto2, and eto 3 mutations and cytokinin treatment increase ethylene biosynthesis in Arabidopsis by increasing the stability of ACS protein. Plant Cell 15, 545-559. doi: 10.1105/tpc.006882

Chang, C., Kwok, S. F., Bleecker, A. B., and Meyerowitz, E. M. (1993). Arabidopsis ethylene-response gene ETR1: similarity of product to two-component regulators. Science 262, 539-544. doi: 10.1126/science.8211181

Chao, Q., Rothenberg, M., Solano, R., Roman, G., Terzaghi, W., and Ecker, J. R. (1997). Activation of the ethylene gas response pathway in Arabidopsis by the nuclear protein ethylene-insensitive3 and related proteins. Cell 89, 1133-1144. doi: 10.1016/S0092-8674(00)80300-1

Chen, Z., Agnew, J. L., Cohen, J. D., He, P., Shan, L., Sheen, J., et al. (2007). Pseudomonas syringae type III effector AvrRpt2 alters Arabidopsis thaliana auxin physiology. Proc. Natl. Acad. Sci. U.S.A. 104, 20131-20136. doi: 10.1073/pnas.0704901104

Chisholm, S. T., Coaker, G., Day, B., and Staskawicz, B. J. (2006). Host-microbe interactions: shaping the evolution of the plant immune response. Cell 124, 803814. doi: 10.1016/j.cell.2006.02.008

Choi, J., Choi, D., Lee, S., Ryu, C.-M., and Hwang, I. (2011). Cytokinins and plant immunity: old foes or new frieds? Trends Plant Sci. 16, 388-394. doi: 10.1016/j.tplants.2011.03.003

Choi, J., Huh, S. U., Kojima, M., Sakakibara, H., Paek, K.-H., and Hwang, I. (2010). The cytokinin-activated transcription factor ARR2 promotes plant immunity via TGA3/NPR1-dependent salicylic acid signaling in Arabidopsis. Dev. Cell 19, 284-295. doi: 10.1016/j.devcel.2010.07.011

Chung, H. S., Koo, A. J. K., Gao, X., Jayanty, S., Thines, B., Jones, A. D., et al. (2008). Regulation and function of Arabidopsis JASMONATE ZIM-domain genes in response to wounding and herbivory. Plant Physiol. 146, 952-964. doi: 10.1104/pp.107.115691

Cui, J., Bahrami, A. K., Pringle, E. G., Hernandez-Guzman, G., Bender, C. L., Pierce, N. E., et al. (2005). Pseudomonas syringae manipulates systemic plant defenses against pathogens and herbivores. Proc. Natl. Acad. Sci. U.S.A. 102, 1791-1796. doi: 10.1073/pnas.0409450102

Cutcliffe, J. W., Hellmann, E., Heyl, A., and Rashotte, A. M. (2011). CRFs form protein-protein interactions with each other and with members of the cytokinin signalling pathway in Arabidopsis via the CRF domain. J. Exp. Bot. 62, 4995-5002. doi: 10.1093/jxb/err199

Cutler, S. R., Rodriguez, P. L., Finkelstein, R. R., and Abrams, S. R. (2010). Abscisic acid: emergence of a core signaling network. Annu. Rev. Plant Biol. 61, 651-679. doi: 10.1146/annurev-arplant-042809-112122

Dangl, J. L., and Jones, J. D. G. (2001). Plant pathogens and integrated defence responses to infection. Nature 411, 826-833. doi: 10.1038/35081161

Davies, W. J., Kudoyarova, G., and Hartung, W. (2005). Long-distance ABA signaling and its relation to other signaling pathways in the detection of soil drying and the mediation of the plant's response to drought. J. Plant Growth Regul. 24, 285-295. doi: 10.1007/s00344-005-0103-1

De Clercq, E. (1998). Carbocyclic adenosine analogues as S-adenosylhomocysteine hydrolase inhibitors and antiviral agents: recent advances. Nucleosides Nucleotides 17, 625-634. doi: 10.1080/07328319808005205

Debnath, M., Pandey, M., and Bisen, P. S. (2011). An omics approach to understand the plant abiotic stress. OMICS 15, 739-762. doi: 10.1089/omi.2010.0146

Delaney, T. P., Uknes, S., Vernooij, B., Friedrich, L., Weymann, K., Negrotto, D., et al. (1994). A central role of salicylic acid in plant disease resistance. Science 266, 1247-1250. doi: 10.1126/science.266.5188.1247

Dermastia, M., Ravnikar, M., Vilhar, B., and Kovač, M. (1994). Increased level of cytokinin ribosides in jasmonic acid-treated potato (Solanum tuberosum) stem node cultures. Physiol. Plant. 92, 241-246. doi: 10.1111/j.13993054.1994.tb05332.x

Dervinis, C., Frost, C. J., Lawrence, S. D., Novak, N. G., and Davis, J. M. (2010). Cytokinin primes plant responses to wounding and reduces insect performance. J. Plant Growth Regul. 29, 289-296. doi: 10.1007/s00344-009-9135-2

Devoto, A., Nieto-Rostro, M., Xie, D., Ellis, C., Harmston, R., Patrick, E., et al. (2002). COI1 links jasmonate signalling and fertility to the SCF ubiquitin-ligase complex in Arabidopsis. Plant J. 32, 457-466. doi: 10.1046/j.1365-313X.2002. 01432.x

Dietz, K.-J., Vogel, M. O., and Viehhauser, A. (2010). AP2/EREBP transcription factors are part of gene regulatory networks and integrate metabolic, hormonal and environmental signals in stress acclimation and retrograde signalling. Protoplasma 245, 3-14. doi: 10.1007/s00709-010-0142-8

Doares, S. H., Narváez-Vásquez, J., Conconi, A., and Ryan, C. A. (1995). Salicylic acid inhibits synthesis of proteinase inhibitors in tomato leaves induced by systemin and jasmonic acid. Plant Physiol. 108, 1741-1746. doi: 10.1104/pp.108.4.1741

Durrant, W. E., and Dong, X. (2004). Systemic acquired resistance. Annu. Rev. Phytopathol. 42, 185-209. doi: 10.1146/annurev.phyto.42.040803.140421

Ferrari, S., Galletti, R., Denoux, C., De Lorenzo, G., Ausubel, F. M., and Dewdney, J. (2007). Resistance to Botrytis cinerea induced in Arabidopsis by elicitors is independent of salicylic acid, ethylene, or jasmonate signaling 
but requires PHYTOALEXIN DEFICIENT3. Plant Physiol. 144, 367-379. doi 10.1104/pp.107.095596

Feys, B. J., and Parker, J. E. (2000). Interplay of signaling pathways in plant disease resistance. Trends Genet. 16, 449-455. doi: 10.1016/S0168-9525(00)02107-7

Finkelstein, R. R., Gampala, S. S. L., and Rock, C. D. (2002). Abscisic acid signaling in seeds and seedlings. Plant Cell 14, S15-S45.

Flor, H. H. (1971). Current status of the gene-for-gene concept. Annu. Rev. Phytopathol. 9, 275-296. doi: 10.1146/annurev.py.09.090171.001423

Fonseca, S., Chico, J. M., and Solano, R. (2009). The jasmonate pathway: the ligand, the receptor and the core signalling module. Curr. Opin. Plant Biol. 12, 539-547. doi: 10.1016/j.pbi.2009.07.013

Fujii, H., and Zhu, J.-K. (2009). Arabidopsis mutant deficient in 3 abscisic acidactivated protein kinases reveals critical roles in growth, reproduction, and stress. Proc. Natl. Acad. Sci. U.S.A. 106, 8380-8385. doi: 10.1073/pnas.0903144106

Fujita, Y., Fujita, M., Shinozaki, K., and Yamaguchi-Shinozaki, K. (2011). ABAmediated transcriptional regulation in response to osmotic stress in plants. $J$. Plant Res. 124, 509-525. doi: 10.1007/s10265-011-0412-3

Gaffney, T., Friedrich, L., Vernooij, B., Negrotto, D., Nye, G., Uknes, S., et al. (1993). Requirement of salicylic acid for the induction of systemic acquired resistance. Science 261, 754-756. doi: 10.1126/science.261.5122.754

Geraats, B. P. J., Bakker, P. A. H. M., Lawrence, C. B., Achuo, E. A., Höfte, M., and van Loon, L. C. (2003). Ethylene-insensitive tobacco shows differentially altered susceptibility to different pathogens. Phytopathology 93, 813-821. doi: 10.1094/PHYTO.2003.93.7.813

Gfeller, A., Liechti, R., and Farmer, E. E. (2010). Arabidopsis jasmonate signaling pathway. Sci. Signal. 3 , cm4. doi: $10.1126 /$ scisignal. $3109 \mathrm{~cm} 4$

Ghanem, M. E., Albacete, A., Smigocki, A. C., Frébort, I., Pospíšilová, H., MartínezAndújar, C., et al. (2011). Root-synthesized cytokinins improve shoot growth and fruit yield in salinized tomato (Solanum lycopersicum L.) plants. J. Exp. Bot. 62, 125-140. doi: 10.1093/jxb/erq266

Goda, H., Sasaki, E., Akiyama, K., Maruyama-Nakashita, A., Nakabayashi, K., Li, W., et al. (2008). The AtGenExpress hormone and chemical treatment data set: experimental design, data evaluation, model data analysis and data access. Plant J. 55, 526-542. doi: 10.1111/j.1365-313X.2008.03510.x

Gómez-Gómez, L. (2004). Plant perception systems for pathogen recognition and defence. Mol. Immunol. 41, 1055-1062. doi: 10.1016/j.molimm.2004.06.008

Gonzalez-Guzman, M., Pizzio, G. A., Antoni, R., Vera-Sirera, F., Merilo, E., Bassel, G. W., et al. (2012). Arabidopsis PYR/PYL/RCAR receptors play a major role in quantitative regulation of stomatal aperture and transcriptional response to abscisic acid. Plant Cell 24, 2483-2496. doi: 10.1105/tpc.112.098574

Greenberg, J. T., and Yao, N. (2004). The role and regulation of programmed cell death in plant - pathogen interactions. Cell. Microbiol. 6, 201-211. doi: 10.1111/j.1462-5822.2004.00361.x

Großkinsky, D. K., Naseem, M., Abdelmohsen, U. R., Plickert, N., Engelke, T., Griebel, T., et al. (2011). Cytokinins mediate resistance against Pseudomona syringae in tobacco through increased antimicrobial phytoalexin synthesis independent of salicylic acid signaling. Plant Physiol. 157, 815-830. doi: 10.1104/pp.111.182931

Guo, H., and Ecker, J. R. (2003). Plant responses to ethylene gas are mediated by SCFEBF1/EBF2-dependent proteolysis of EIN3 transcription factor. Cell 115, 667-677. doi: 10.1016/S0092-8674(03)00969-3

Guzmán, P., and Ecker, J. R. (1990). Exploiting the triple response of Arabidopsis to identify ethylene-related mutants. Plant Cell 2, 513-523.

Hammond-Kosack, K. E., and Jones, J. D. G. (1996). Resistance gene-dependent plant defense responses. Plant Cell 8, 1773-1791.

Hansen, H., and Dörffling, K. (2003). Root-derived trans-zeatin riboside and abscisic acid in drought-stressed and rewatered sunflower plants: interaction in the control of leaf diffusive resistance? Funct. Plant Biol. 30, 365-375. doi 10.1071/FP02223

Hansen, M., Chae, H. S., and Kieber, J. J. (2009). Regulation of ACS protein stability by cytokinin and brassinosteroid. Plant J. 57, 606-614. doi 10.1111/j.1365-313X.2008.03711.x

Hirayama, T., and Shinozaki, K. (2010). Research on plant abiotic stress responses in the post-genome era: past, present and future. Plant J. 61, 1041-1052. doi 10.1111/j.1365-313X.2010.04124.x

Hua, J., Chang, C., Sun, Q., and Meyerowitz, E. M. (1995). Ethylene insensitivity conferred by Arabidopsis ERS gene. Science 269, 1712-1714. doi: $10.1126 /$ science. 7569898
Hua, J., Sakai, H., Nourizadeh, S., Chen, Q. G., Bleecker, A. B., Ecker, J. R., et al. (1998). EIN4 and ERS2 are members of the putative ethylene receptor gene family in Arabidopsis. Plant Cell 10, 1321-1332.

Hutchison, C. E., Li, J., Argueso, C., Gonzalez, M., Lee, E., Lewis, M. W., et al. (2006). The Arabidopsis histidine phosphotransfer proteins are redundant positive regulators of cytokinin signaling. Plant Cell 18, 3073-3087. doi: $10.1105 /$ tpc. 106.045674

Hwang, I., and Sheen, J. (2001). Two-component circuitry in Arabidopsis cytokinin signal transduction. Nature 413, 383-389. doi: 10.1038/35096500

Hwang, I., Sheen, J., and Müller, B. (2012). Cytokinin signaling networks. Annu. Rev. Plant Biol. 63, 353-380. doi: 10.1146/annurev-arplant-042811-105503

Igari, K., Endo, S., Hibara, K.-I., Aida, M., Sakakibara, H., Kawasaki, T., et al. (2008). Constitutive activation of a CC-NB-LRR protein alters morphogenesis through the cytokinin pathway in Arabidopsis. Plant J. 55, 14-27. doi: 10.1111/j.1365313X.2008.03466.x

Jeon, J., and Kim, J. (2013). Arabidopsis response regulatorl and Arabidopsis histidine phosphotransfer protein2 (AHP2), AHP3, and AHP5 function in cold signaling. Plant Physiol. 161, 408-424. doi: 10.1104/pp.112.207621

Jeon, J., Kim, N. Y., Kim, S., Kang, N. Y., Novák, O., Ku, S.-J., et al. (2010). A subset of cytokinin two-component signaling system plays a role in cold temperature stress response in Arabidopsis. J. Biol. Chem. 285, 23371-23386. doi: 10.1074/jbc.M109.096644

Jones, J. D. G., and Dangl, J. L. (2006). The plant immune system. Nature 444, 323-329. doi: 10.1038/nature05286

Kamada, I., Yamauchi, S., Youssefian, S., and Sano, H. (1992). Transgenic tobacco plants expressing rpgl, a gene encoding a ras-related GTP-binding protein from rice, show distinct morphological characteristics. Plant J. 2, 799-807. doi: 10.1111/j.1365-313X.1992.tb00149.x

Kang, N. Y., Cho, C., Kim, N. Y., and Kim, J. (2012). Cytokinin receptor-dependent and receptor-independent pathways in the dehydration response of Arabidopsis thaliana. J. Plant Physiol. 169, 1382-1391. doi: 10.1016/j.jplph.2012.05.007

Kanzaki, H., Saitoh, H., Ito, A., Fujisawa, S., Kamoun, S., Katou, S., et al. (2003). Cytosolic HSP90 and HSP70 are essential components of INF1-mediated hypersensitive response and non-host resistance to Pseudomonas cichorii in Nicotiana benthamiana. Mol. Plant Pathol. 4, 383-391. doi: 10.1046/j.13643703.2003.00186.x

Kieber, J. J., Rothenberg, M., Roman, G., Feldmann, K. A., and Ecker, J. R. (1993). CTR1, a negative regulator of the ethylene response pathway in Arabidopsis, encodes a member of the Raf family of protein kinases. Cell 72, 427-441. doi: 10.1016/0092-8674(93)90119-B

Kilian, J., Whitehead, D., Horak, J., Wanke, D., Weinl, S., Batistic, O., et al. (2007). The AtGenExpress global stress expression data set: protocols, evaluation and model data analysis of UV-B light, drought and cold stress responses. Plant J. 50, 347-363. doi: 10.1111/j.1365-313X.2007.03052.x

Kloek, A. P., Verbsky, M. L., Sharma, S. B., Schoelz, J. E., Vogel, J., Klessig, D. F., et al. (2001). Resistance to Pseudomonas syringae conferred by an Arabidopsis thaliana coronatine-insensitive (coil) mutation occurs through two distinct mechanisms. Plant J. 26, 509-522. doi: 10.1046/j.1365-313x.2001.01050.x

Kudoyarova, G. R., Vysotskaya, L. B., Cherkozyanova, A., and Dodd, I. C. (2007). Effect of partial rootzone drying on the concentration of zeatin-type cytokinins in tomato (Solanum lycopersicum L.) xylem sap and leaves. J. Exp. Bot. 58, 161-168. doi: $10.1093 / \mathrm{jxb} / \mathrm{erl} 116$

Kushwah, S., Jones, A. M., and Laxmi, A. (2011). Cytokinin interplay with ethylene, auxin, and glucose signaling controls Arabidopsis seedling root directional growth. Plant Physiol. 156, 1851-1866. doi: 10.1104/pp.111.175794

Lehotai, N., Kolbert, Z., Petó, A., Feigl, G., Ördög, A., Kumar, D., et al. (2012). Selenite-induced hormonal and signalling mechanisms during root growth of Arabidopsis thaliana L. J. Exp. Bot. 63, 5677-5687. doi: 10.1093/jxb/ers222

Liang, Y. S., Ermawati, N., Cha, J.-Y., Jung, M. H., Su'udi, M., Kim, M. G., et al. (2010). Overexpression of an AP2/ERF-type transcription factor CRF5 confers pathogen resistance to Arabidopsis plants. J. Korean Soc. Appl. Biol. Chem. 53, 142-148. doi: 10.3839/jksabc.2010.024

Ma, Y., Szostkiewicz, I., Korte, A., Moes, D., Yang, Y., Christmann, A., et al. (2009). Regulators of PP2C phosphatase activity function as abscisic acid sensors. Science 324, 1064-1068.

Malamy, J., Carr, J. P., Klessig, D. F., and Raskin, I. (1990). Salicylic acid: a likely endogenous signal in the resistance response of tobacco to viral infection. Science 250, 1002-1004. doi: 10.1126/science.250.4983.1002 
Mason, M. G., Jha, D., Salt, D. E., Tester, M., Hill, K., Kieber, J. J., et al. (2010). Type-B response regulators ARR1 and ARR12 regulate expression of AtHKT1;1 and accumulation of sodium in Arabidopsis shoots. Plant J. 64, 753-763. doi: 10.1111/j.1365-313X.2010.04366.x

Masuta, C., Tanaka, H., Uehara, K., Kuwata, S., Koiwai, A., and Noma, M. (1995). Broad resistance to plant viruses in transgenic plants conferred by antisense inhibition of a host gene essential in S-adenosylmethionine-dependent transmethylation reactions. Proc. Natl. Acad. Sci. U.S.A. 92, 6117-6121. doi 10.1073/pnas.92.13.6117

McCabe, M. S., Garratt, L. C., Schepers, F., Jordi, W. J. R. M., Stoopen, G. M., Davelaar, E., et al. (2001). Effects of PSAG12-IPT gene expression on development and senescence in transgenic lettuce. Plant Physiol. 127, 505-516. doi: 10.1104/pp.010244

Mou, Z., Fan, W., and Dong, X. (2003). Inducers of plant systemic acquired resistance regulate NPR1 function through redox changes. Cell 113, 935-944. doi: 10.1016/S0092-8674(03)00429-X

Mur, L. A. J., Kenton, P., Atzorn, R., Miersch, O., and Wasternack, C. (2006). The outcomes of concentration-specific interactions between salicylate and jasmonate signaling include synergy, antagonism, and oxidative stress leading to cell death. Plant Physiol. 140, 249-262. doi: 10.1104/pp.105.072348

Naik, G. R., Mukherjee, I., and Reid, D. M. (2002). Influence of cytokinins on the methyl jasmonate-promoted senescence in Helianthus annuus cotyledons. Plant Growth Regul. 38, 61-68. doi: 10.1023/A:1020926902352

Naseem, M., and Dandekar, T. (2012). The role of auxin-cytokinin antagonism in plant-pathogen interactions. PLoS Pathog. 8:e1003026. doi: 10.1371/journal.ppat.1003026

Naseem, M., Philippi, N., Hussain, A., Wangorsch, G., Ahmed, N., and Dandekar, T. (2012). Integrated systems view on networking by hormones in Arabidopsi immunity reveals multiple crosstalk for cytokinin. Plant Cell 24, 1793-1814. doi: 10.1105/tpc.112.098335

Nemhauser, J. L., Hong, F., and Chory, J. (2006). Different plant hormones regulate similar processes through largely nonoverlapping transcriptional responses. Cell 126, 467-475. doi: 10.1016/j.cell.2006.05.050

Nishimura, M. T., and Dangl, J. L. (2010). Arabidopsis and the plant immune system. Plant J. 61, 1053-1066. doi: 10.1111/j.1365-313X.2010.04131.x

Nishimura, N., Sarkeshik, A., Nito, K., Park, S.-Y., Wang, A., Carvalho, P. C. et al. (2010). PYR/PYL/RCAR family members are major in vivo ABI1 protein phosphatase 2C-interacting proteins in Arabidopsis. Plant J. 61, 290-299. doi: 10.1111/j.1365-313X.2009.04054.x

Nishimura, N., Yoshida, T., Kitahata, N., Asami, T., Shinozaki, K., and Hirayama, T. (2007). ABA-hypersensitive germinationl encodes a protein phosphatase 2C, an essential component of abscisic acid signaling in Arabidopsis seed. Plant J. 50, 935-949. doi: 10.1111/j.1365-313X.2007.03107.x

Nishiyama, R., Watanabe, Y., Leyva-Gonzalez, M. A., Ha, C. V., Fujita, Y., Tanaka, M., et al. (2013). Arabidopsis AHP2, AHP3, and AHP5 histidine phosphotransfer proteins function as redundant negative regulators of drought stress response. Proc. Natl. Acad. Sci. U.S.A. 110, 4840-4845. doi: 10.1073/pnas.1302265110

Nishiyama, R., Watanabe, Y., Fujita, Y., Le, D. T., Kojima, M., Werner, T., et al (2011). Analysis of cytokinin mutants and regulation of cytokinin metabolic genes reveals important regulatory roles of cytokinins in drought, salt and abscisic acid responses, and abscisic acid biosynthesis. Plant Cell 23, 2169-2183. doi: $10.1105 /$ tpc. 111.087395

Overmyer, K., Tuominen, H., Kettunen, R., Betz, C., Langebartels, C., Sandermann, H. Jr., et al. (2000). Ozone-sensitive Arabidopsis rcd1 mutant reveals opposite roles for ethylene and jasmonate signaling pathways in regulating superoxidedependent cell death. Plant Cell 12, 1849-1862.

Park, S.-W., Kaimoyo, E., Kumar, D., Mosher, S., and Klessig, D. F. (2007). Methyl salicylate is a critical mobile signal for plant systemic acquired resistance. Science 318, 113-116 [Erratum Science 321, 342]. doi: 10.1126/science.1147113

Park, S.-Y., Fung, P., Nishimura, N., Jensen, D. R., Fujii, H., Zhao, Y., et al. (2009). Abscisic acid inhibits type $2 \mathrm{C}$ protein phosphatases via the PYR/PYL family of START proteins. Science 324, 1068-1071.

Peña-Cortés, H., Albrecht, T., Prat, S., Weiler, E. W., and Willmitzer, L. (1993). Aspirin prevents wound-induced gene expression in tomato leaves by blocking jasmonic acid biosynthesis. Planta 191, 123-128.

Petersen, M., Brodersen, P., Naested, H., Andreasson, E., Lindhart, U., Johansen, B., et al. (2000). Arabidopsis MAP kinase 4 negatively regulates systemic acquired resistance. Cell 103, 1111-1120. doi: 10.1016/S0092-8674(00)00213-0
Potuschak, T., Lechner, E., Parmentier, Y., Yanagisawa, S., Grava, S., Koncz, C., et al. (2003). EIN3-dependent regulation of plant ethylene hormone signaling by two Arabidopsis F bos proteins: EBF1 and EBF2. Cell 115, 679-689. doi: 10.1016/S0092-8674(03)00968-1

Qin, H., Gu, Q., Zhang, J., Sun, L., Kuppu, S., Zhang, Y., et al. (2011). Regulated expression of an isopentenyltransferase gene (IPT) in peanut significantly improves drought tolerance and increases yield under field conditions. Plant Cell Physiol. 52, 1904-1914. doi: 10.1093/pcp/pcr125

Rabbani, M. A., Maruyama, K., Abe, H., Khan, M. A., Katsura, K., Ito, Y., et al. (2003). Monitoring expression profiles of rice genes under cold, drought, and high-salinity stresses and abscisic acid application using cDNA microarray and RNA get-blot analyses. Plant Physiol. 133, 1755-1767. doi: 10.1104/pp.103.025742 Raghavendra, A. S., Gonugunta, V. K., Christmann, A., and Grill, E. (2010). ABA perception and signalling. Trends Plant Sci. 15, 395-401. doi: 10.1016/j.tplants.2010.04.006

Rashotte, A. M., Mason, M. G., Hutchison, C. E., Ferreira, F. J., Schaller, G. E., and Kieber, J. J. (2006). A subset of Arabidopsis AP2 transcription factors mediates cytokinin responses in concert with a two-component pathway. Proc. Natl. Acad. Sci. U.S.A. 103, 11081-11085. doi: 10.1073/pnas.0602038103

Robert-Seilaniantz, A., Navarro, L., Bari, R., and Jones, J. D. G. (2007). Pathological hormone imbalances. Curr. Opin. Plant Biol. 10, 372-379. doi: 10.1016/j.pbi.2007.06.003

Ross, A. F. (1961). Localized acquired resistance to plant virus infection in hypersensitive hosts. Virology 14, 329-339. doi: 10.1016/0042-6822(61) 90318-X

Růžička, K., Ljung, K., Vanneste, S., Podhorská, R., Beeckman, T., Friml, J., et al. (2007). Ethylene regulates root growth through effects on auxin biosynthesis and transport-dependent auxin distribution. Plant Cell 19, 2197-2212. doi: $10.1105 /$ tpc. 107.052126

Sakai, H., Hua, J., Chen, Q. G., Chang, C., Medrano, L. J., Bleecker, A. B., et al. (1998). ETR2 is an ETR1-like gene involved in ethylene signaling in Arabidopsis. Proc. Natl. Acad. Sci. U.S.A. 95, 5812-5817. doi: 10.1073/pnas.95.10. 5812

Sano, H., Seo, S., Orudgev, E., Youssefian, S., Ishizuka, K., and Ohashi, Y. (1994). Expression of the gene for a small GTP binding protein in transgenic tobacco elevates endogenous cytokinin levels, abnormally induces salicylic acid in response to wounding, and increases resistance to tobacco mosaic virus infection. Proc. Natl. Acad. Sci. U.S.A. 91, 10556-10560. doi: 10.1073/pnas.91.22.10556

Sano, H., Seo, S., Koizumi, N., Niki, T., Iwamura, H., and Ohashi, Y. (1996) Regulation of cytokinins of endogenous levels of jasmonic and salicylic acids in mechanically wounded tobacco plants. Plant Cell Physiol. 37, 762-769 doi: 10.1093/oxfordjournals.pcp.a029011

Santiago, J., Dupeux, F., Round, A., Antoni, R., Park, S.-Y., Jamin, M., et al. (2009a) The abscisic acid receptor PYR1 in complex with abscisic acid. Nature 462, 665668. doi: 10.1038/nature08591

Santiago, J., Rodrigues, A., Saez, A., Rubio, S., Antoni, R., Dupeux, F., et al. (2009b). Modulation of drought resistance by the abscisic acid receptor PYL5 through inhibition of clade A PP2Cs. Plant J. 60, 575-588. doi: 10.1111/j.1365-313X.2009.03981.x

Schachtman, D. P., and Goodger, J. Q. D. (2008). Chemical root to shoot signaling under drought. Trends Plant Sci. 13, 281-287. doi: 10.1016/j.tplants.2008.04.003

Seki, M., Narusaka, M., Ishida, J., Nanjo, T., Fujita, M., Oono, Y., et al. (2002) Monitoring the expression profiles of 7000 Arabidopsis genes under drought, cold and high-salinity stresses using a full-length cDNA microarray. Plant J. 31, 279-292. doi: 10.1046/j.1365-313X.2002.01359.x

Shi, Y., Tian, S., Hou, L., Huang, X., Zhang, X., Guo, H., et al. (2012). Ethylene signaling negatively regulates freezing tolerance by repressing expression of CBF and type-A ARR genes in Arabidopsis. Plant Cell 24, 2578-2595. doi: 10.1105/tpc.112.098640

Shkolnik-Inbar, D., and Bar-Zvi, D. (2010). ABI4 mediates abscisic acid and cytokinin inhibition of lateral root formation by reducing polar auxin transport in Arabidopsis. Plant Cell 22, 3560-3573. doi: 10.1105/tpc.110.074641

Sreenivasulu, N., Sopory, S. K., and Kavi Kishor, P. B. (2007). Deciphering the regulatory mechanisms of abiotic stress tolerance in plants by genomic approaches. Gene 388, 1-13. doi: 10.1016/j.gene.2006.10.009

Stoll, M., Loveys, B., and Dry, P. (2000). Hormonal changes induced by partial rootzone drying of irrigated grapevine. J. Exp. Bot. 51, 1627-1634. doi: $10.1093 /$ jexbot/51.350.1627 
Stoynova-Bakalova, E., Petrov, P. I., Gigova, L., and Baskin, T. I. (2008). Differential effects of methyl jasmonate on growth and division of etiolated zucchini cotyledons. Plant Biol. 10, 476-484. doi: 10.1111/j.1438-8677.2008.00034.x

Sýkorová, B., Kurešová, G., Daskalova, S., Trčková, M., Hoyerová, K., Raimanová, I., et al. (2008). Senescence-induced ectopic expression of the A.tumefaciens ipt gene in wheat delays leaf senescence, increases cytokinin content, nitrate influx, and nitrate reductase activity, but does not affect grain yield. J. Exp. Bot. 59, 377-387. doi: 10.1093/jxb/erm319

Szostkiewicz, I., Richter, K., Kepka, M., Demmel, S., Ma, Y., Korte, A., et al. (2010). Closely related receptor complexes differ in their ABA selectivity and sensitivity. Plant J. 61, 25-35. doi: 10.1111/j.1365-313X.2009.04025.x

Thaler, J. S., Humphrey, P. T., and Whiteman, N. K. (2012). Evolution of jasmonate and salicylate signal crosstalk. Trends Plant Sci. 17, 260-270. doi: 10.1016/j.tplants.2012.02.010

To, J. P. C., and Kieber, J. J. (2008). Cytokinin signaling: two-components and more. Trends Plant Sci. 13, 85-92. doi: 10.1016/j.tplants.2007.11.005

Tran, L.-S. P., Urao, T., Qin, F., Maruyama, K., Kakimoto, T., Shinozaki, K., et al. (2007). Functional analysis of AHK1/ATHK1 and cytokinin receptor histidine kinases in response to abscisic acid, drought, and salt stress in Arabidopsis. Proc Natl. Acad. Sci. U.S.A. 104, 20623-20628. doi: 10.1073/pnas.0706547105

Truman, W., Bennettt, M. H., Kubigsteltig, I., Turnbull, C., and Grant, M. (2007) Arabidopsis systemic immunity uses conserved defense signaling pathways and is mediated by jasmonates. Proc. Natl. Acad. Sci. U.S.A. 104, 1075-1080. doi: 10.1073/pnas.0605423104

Ueda, J., and Kato, J. (1982). Inhibition of cytokinin-induced plant growth by jasmonic acid and its methyl ester. Physiol. Plant. 54, 249-252. doi: 10.1111/j.1399-3054.1982.tb00255.x

Umezawa, T., Sugiyama, N., Mizoguchi, M., Hayashi, S., Myouga, F., YamaguchiShinozaki, K., et al. (2009). Type 2C protein phosphatases directly regulate abscisic acid-activated protein kinases in Arabidopsis. Proc. Natl. Acad. Sci. U.S.A 106, 17588-17593. doi: 10.1073/pnas.0907095106

Urao, T., Yakubov, B., Satoh, R., Yamaguchi-Shinozaki, K., Seki, M., Hirayama T., et al. (1999). A transmembrane hybrid-type histidine kinase in Arabidopsis functions as an osmosensor. Plant Cell 11, 1743-1754.

van Wees, S. C. M., Chang, H.-S., Zhu, T., and Glazebrook, J. (2003). Characterization of the early response of Arabidopsis to Alternaria brassicicola infection using expression profiling. Plant Physiol. 132, 606-617. doi: 10.1104/pp.103.022186

Vanstraelen, M., and Benková, E. (2012). Hormonal interactions in the regulation of plant development. Annu. Rev. Cell Dev. Biol. 28, 463-487. doi: 10.1146/annurevcellbio-101011-155741

Vlad, F., Rubio, S., Rodrigues, A., Sirichandra, C., Belin, C., Robert, N., et al (2009). Protein phosphatases 2C regulate the activation of the Snfl-related kinase OST1 by abscisic acid in Arabidopsis. Plant Cell 21, 3170-3184. doi: 10.1105/tpc.109.069179

Vogel, J. P., Woeste, K. E., Theologis, A., and Kieber, J. J. (1998). Recessive and dominant mutations in the ethylene biosynthetic gene ACS5 of Arabidopsis confer cytokinin insensitivity and ethylene overproduction, respectively. Proc. Natl. Acad. Sci. U.S.A. 95, 4766-4771. doi: 10.1073/pnas.95.8.4766

Wang, L., Hua, D., He, J., Duan, Y., Chen, Z., Hong, X., et al. (2011a) Auxin Response Factor2 (ARF2) and its regulated homeodomain gene HB33 mediate abscisic acid response in Arabidopsis. PLoS Genet. 7:e1002172. doi: 10.1371/journal.pgen.1002172

Wang, Y., Li, L., Ye, T., Zhao, S., Liu, Z., Feng, Y.-Q., et al. (2011b). Cytokinin antagonizes ABA suppression to seed germination of Arabidopsis by downregulating ABI5 expression. Plant J. 68, 249-261. doi: 10.1111/j.1365-313X.2011.04683.x

Werner, T., Nehnevajova, E., Köllmer, I., Novák, O., Strnad, M., Krämer, U., et al. (2010). Root-specific reduction of cytokinin causes enhanced root growth, drought tolerance, and leaf mineral enrichment in Arabidopsis and tobacco. Plant Cell 22, 3905-3920. doi: 10.1105/tpc.109.072694
Wind, J. J., Peviani, A., Snel, B., Hanson, J., and Smeekens, S. C. (2013). ABI4: versatile activator and repressor. Trends Plant Sci. 18, 125-132. doi: 10.1016/j.tplants.2012.10.004

Xu, J., Li, X.-L., and Luo, L. (2012). Effects of engineered Sinorhizobium meliloti on cytokinin synthesis and tolerance of alfalfa to extreme drought stress. Appl. Environ. Microbiol. 78, 8056-8061. doi: 10.1128/AEM.01276-12

Xu, L., Liu, F., Lechner, E., Genschik, P., Crosby, W. L., Ma, H., et al. (2002). The SCFCOI1 ubiquitin-ligase complexes are required for jasmonate response in Arabidopsis. Plant Cell 14, 1919-1935. doi: 10.1105/tpc.003368

Yarwood, C. E. (1960). Topical susceptibility of plants to viruses. Virology 12, 245257. doi: 10.1016/0042-6822(60)90198-7

Ye, M., Luo, S. M., Xie, J. F., Li, Y. F., Xu, T., Liu, Y., et al. (2012). Silencing COI1 in rice increases susceptibility to chewing insects and impairs inducible defense. PLoS ONE 7:e36214. doi: 10.1371/journal.pone.0036214

Žd'árská, M., Zatloukalová, P., Benítez, M., Šedo, O., Potěšil, D., Novák, O., et al (2013). Proteome analysis in Arabidopsis reveals shoot- and root-specific targets of cytokinin action and differential regulation of hormonal homeostasis. Plant Physiol. 161, 918-930. doi: 10.1104/pp.112.202853

Zeller, G., Henz, S. R., Widmer, C. K., Sachsenberg, T., Rätsch, G., Weigel, D., et al. (2009). Stress-induced changes in the Arabidopsis thaliana transcriptome analyzed using whole-genome tiling arrays. Plant J. 58, 1068-1082. doi: 10.1111/j.1365-313X.2009.03835.x

Zhai, Y., Wang, Y., Li, Y., Lei, T., Yan, F., Su, L., et al. (2013). Isolation and molecular characterization of GmERF7, a soybean ethylene-response factor that increases salt stress tolerance in tobacco. Gene 513, 174-183. doi: 10.1016/j.gene.2012.10.018

Zhang, Y., Fan, W., Kinkema, M., Li, X., and Dong, X. (1999). Interaction of NPR1 with basic leucine zipper protein transcription factors that bind sequences required for salicylic acid induction of the PR-1 gene. Proc. Natl. Acad. Sci. U.S.A. 96, 6523-6528. doi: 10.1073/pnas.96.11.6523

Zhu, Z., An, F., Feng, Y., Li, P., Xue, L., A, M., et al. (2011). Derepression of ethylenestabilized transcription factors (EIN3/EIL1) mediates jasmonate and ethylene signaling synergy in Arabidopsis. Proc. Natl. Acad. Sci. U.S.A. 108, 12539-12544. doi: 10.1073/pnas.1103959108

Zipfel, C., Kunze, G., Chinchilla, D., Caniard, A., Jones, J. D. G., Boller, T., etal. (2006). Perception of the bacterial PAMP EF-Tu by the receptor EFR restricts Agrobacterium-mediated transformation. Cell 125, 749-760. doi: 10.1016/j.cell.2006.03.037

Zwack, P. J., Robinson, B. R., Risley, M. G., and Rashotte, A. M. (2013). Cytokinin response factor 6 negatively regulates leaf senescence and is induced in response to cytokinin and numerous abiotic stresses. Plant Cell Physiol. 54, 971-981. doi: $10.1093 / \mathrm{pcp} / \mathrm{pct} 049$

Conflict of Interest Statement: The authors declare that the research was conducted in the absence of any commercial or financial relationships that could be construed as a potential conflict of interest.

Received: 21 January 2013; accepted: 22 October 2013; published online: 19 November 2013.

Citation: O'Brien JA and Benková E (2013) Cytokinin cross-talking during biotic and abiotic stress responses. Front. Plant Sci. 4:451. doi: 10.3389/fpls.2013.00451

This article was submitted to Plant Cell Biology, a section of the journal Frontiers in Plant Science.

Copyright (c) 2013 O'Brien and Benková. This is an open-access article distributed under the terms of the Creative Commons Attribution License (CC BY). The use, distribution or reproduction in other forums is permitted, provided the original author(s) or licensor are credited and that the original publication in this journal is cited, in accordance with accepted academic practice. No use, distribution or reproduction is permitted which does not comply with these terms. 